\title{
Detection of microbial activity in some organic amendments
}

\author{
My Ngan Ngo ${ }^{1}$ and Nuntavun Riddech ${ }^{2,3^{*}}$ \\ ${ }^{1}$ M.Sc. in Biological Science International Program, Faculty of Science, Khon Kaen University, Thailand \\ 2Department of Microbiology, Faculty of Science, Khon Kaen University, Thailand \\ ${ }^{3}$ Salt-tolerant Rice Research Group, Faculty of Science, Khon Kaen University, Khon Kaen, 40002, Thailand \\ Email: nunrid@kku.ac.th
}

Received 15 May 2017; Received in revised form 12 August 2017; Accepted 11 October 2017

\begin{abstract}
Aims: In this paper we conducted a laboratory experiment to assess the biological characters and maturity level of three organic materials: filter cake (FC), spent mushroom substrate (SMS) and fermented grass (FG), through microbial activity and phytotoxicity.

Methodology and results: Each sample was determined for physicochemical parameters, microbial activity and phytotoxicity. Microorganism population was counted by spreading plate method and microbial activities were tested by measuring fluorescein diacetate (FDA) hydrolysis and dehydrogenase activity (DHA). The phytotoxicity evaluation by seed germination was tested on Hibiscus sabdariffa (Roselle), Abelmoschus esculentus (Okra) and Oryza sativa (Rice). The results showed that all substrates have suitable physicochemical values that could be used as soil amendments. These organic matters are a rich source of microorganisms ( $\left.>10^{7} \mathrm{CFU} / \mathrm{g}\right)$, especially plant growth promoting bacteria (ranging from $10^{4}$ to $10^{6} \mathrm{CFU} / \mathrm{g}$ ). The high value of FDA (ranging from 1.609 to $1.621 \mathrm{mg} / \mathrm{g}$ ) and DHA activity (ranging from 153.95 to $179.92 \mu \mathrm{g} / \mathrm{g}$ ) suggested a high degree of microbial activity in the organic amendment samples. Combining with germination index values in seed germination, most Gl values indicate non-toxicity of those substrates, with the exception of fermented grass in germination of $H$. sabdariffa.

Conclusion, significance and impact of study: The result from this study proposes that these substrates can be considered as potential amendments to support soil property.
\end{abstract}

Keywords: Abelmoschus esculentus, Hibiscus sabdariffa, microbial activity, organic amendments, Oryza sativa, phytotoxcity

\section{INTRODUCTION}

Organic matter constitutes only a small proportion in soil composition but plays important roles in soil fertility. As well as providing nutrients for plants and habitation for microorganism, the presence of soil organic matter improves soil's physical, chemical and biological properties (Bot and José, 2005). Intensive agriculture, which typically involves continuous cropping, removal or burning all residues and the over use of fertilizers and pesticides, leads to loss of soil organic matter, thus changing soil characteristics (Sultana, 2011). Lack of soil organic matter decreases water-holding capacity and aggregation, increases bulk density and negatively affects microbial activity (Larney and Angers, 2012).

Application of organic amendments has been used as an effective and economic tool for recovery or maintaining soil health. This method has been shown to enhance soil biological activities as well as improving physical and chemical properties (Silva and Hue, 2000; Diacono and
Framcesco, 2010; Adugna, 2016). Moreover, reuse of organic wastes as soil amendments have the advantage in environmental pollution prevention. However, maturity of these organic substrates should be investigated as some negative effects in the soil-plant system have long been reported (Iglesias Jiménez and Perez Garcia, 1989). Some undesirable compounds such as high salts, heavy metals, pathogens and toxins cause adverse effects on plant growth (Tam and Tiquia 1994; Ferreras et al., 2006). The quality of organic amendments depends on their origin and varies by time. Organic matter decomposition in natural habitats is mainly performed by microbial activity (Burns, 1982). Then, total microbial activity is a good measure for estimation of organic matter turnover. Hydrolysis of fluorescein diacetate (FDA) and dehydrogenase activity (DHA) have been proposed as popular methods to determine total microbial activity due to their accuracy and simplicity with a range of environmental samples (Schnurer and Rosswall, 1982; Trevors, 1984; von Mersi and Schinner, 1991; Adam and 
Duncan, 2001; Gaspar et al., 2001). Determination of enzyme activity is mostly conducted in soil samples to assess soil fertility (Franzlubbers and Haney, 2006), soil degradation or remediation processes (Pascual et al., 2000).

There is currently little information about enzyme activity in organic amendments. Further, there is no completely universal method for evaluating phytotoxicity in soil amendments because their phytotoxicity can arise from many factors. Seed germination is the most general biological method to determine phytotoxcity of compost (Marthur et al., 1993; Tiquia et al., 1996; Warman, 1999; Selim et al., 2012) because it provides direct and reliable information. However, using a single parameter on single plant species was not sensitive enough to detect immaturity of organic matter (Warman, 1999).

The objective of this research is to assess the quality of various organic amendments through microbial activity and phytotoxicity. The result is expected to be useful to farmers and producers on the potential of organic amendments in agricultural application.

\section{MATERIALS AND METHODS}

Three organic substrates were selected in this study: filter cake (FC), spent mushroom substrate (SMS), and fermented grass (FG). Spent mushroom substrate is degraded for at least three months. As a control in this trial, a kind of normal soil taken from a paddy field in Khon Kaen province in the north-east region of Thailand was also used.

\section{Determination of organic substrates' properties}

All substrates were tested for some physicochemical properties. The $\mathrm{pH}$ value was measured in extract solution (sample: water $=1: 5)$. Electrical conductivity $(E C)$ was determined in a 1:5 suspension by conductivity meter. The moisture content of each sample was determined by measurement of fresh weight and dry weight (after oven drying at $105{ }^{\circ} \mathrm{C}$ for $48 \mathrm{~h}$ ). The moisture content was calculated as per the following equation (1):

Moisture content $=($ Initial weight - Final weight $) /$ Initial weight *100 (1)

Nutrient contents in these substrates were determined by standard methods. Total $\mathrm{N}$ was analyzed using the Kjeldahl method and measured by colorimetry. Total phosphorus was measured by the wet oxidation and yellow molybdo vanado phosphoric acid method. Total potassium was assayed by wet oxidation and flame photometer. The Walkley and Black method was used for organic matter analysis.

\section{Assessing of total microorganism and plant growth promoting bacteria population}

Each substrate was assessed for the following: total microorganisms (TM), nitrogen fixing bacteria (NFB), phosphorus solubilizing bacteria (PSB) and potassium solubilizing bacteria (KSB). Ten grams of organic substrate were placed in a sterilized flask containing 90 $\mathrm{mL}$ distilled water and shaken at $150 \mathrm{rpm}$ for one hour. Microbial population was serially diluted and counted by the spreading plate method on specific media. Nutrient agar and nitrogen free medium were used for detecting total microorganisms and nitrogen fixing bacteria, respectively. After spreading, the plates were incubated at $30^{\circ} \mathrm{C}$ for $1-2$ days and number of colonies that grew on these two media was recorded. PBS and KBS populations were determined by spreading on NRIPB (Nautiyal, 1999) and Aleksandrov medium (Hu et al., 2006), respectively; they were then incubated at $30{ }^{\circ} \mathrm{C}$ for $4-5$ days. The colony with halo zone was determined as PSB and KSB.

\section{Fluorescein diacetate (FDA) hydrolysis activity}

In this paper, FDA hydrolysis activity was measured by the modified method of Adam and Duncan (2001). One gram of non-autoclaved sample (fresh weight, sieved $<2$ $\mathrm{mm}$ ) was placed in a falcon tube and mixed with $7.5 \mathrm{~mL}$ potassium phosphate buffer $\mathrm{pH} 7.6$, followed by adding $0.1 \mathrm{~mL}$ of $1000 \mathrm{mg} / \mathrm{mL}$ FDA to start the reaction. Blanks were added with $0.1 \mathrm{~mL}$ of acetone. The test tubes were shaken well by hand before placing in a shaker-incubator at $30{ }^{\circ} \mathrm{C}$ for $30 \mathrm{~min}$. After shaking, $7.5 \mathrm{~mL}$ of chloroform/methanol $(2: 1 \mathrm{v} / \mathrm{v})$ was added immediately to stop the reaction. All tubes were centrifuged at $6000 \mathrm{rpm}$ for $15 \mathrm{~min}$. The supernatant was kept and centrifuged at $10000 \mathrm{rpm}$ for $5 \mathrm{~min}$. The autoclaved samples, known as the control, were prepared similarly. The OD values were measured at $490 \mathrm{~nm}$ on a spectrophotometer. The amount of fluorescein released was calculated using the standard curve of fluorescein standard solution.

\section{Dehydrogenase activity (DHA)}

DHA was determined using INT, 2-(p-lodophenyl)-3(pnitrophenyl)-5-phenyl tetrazolium chloride or $\mathrm{p}$ idonitrotetrazolium violet (von Mersi and Schinner, 1991). A mixture consisting of $1 \mathrm{~g}$ of substrate (moist weight, sieved $<2 \mathrm{~mm}), 1.5 \mathrm{~mL}$ TrisHCl buffer $(1 \mathrm{M}, \mathrm{pH} 7.0)$ and 2 $\mathrm{mL} 0.5 \%$ INT solution was incubated at $40{ }^{\circ} \mathrm{C}$ in the dark for $1 \mathrm{~h}$. For blank samples, distilled water was added instead of INT. After incubation, $10 \mathrm{~mL}$ of extract solution $(\mathrm{N}, \mathrm{N}$-dimethylformamide: ethanol $=1: 1)$ was added to all test tubes, then mixed well and kept in the dark for 30 min. The control was carried out in the same way with autoclaved substrates. The INT formazan (INTF) extraction was filtered using Whatman No. 5 filter paper. The color of INTF was measured by spectrophotometer at $490 \mathrm{~nm}$. These absorption values were calculated as the mg INTF $\mathrm{g}^{-1}$ sample based on a standard curve of INTF (Sigma Chemical Co., 2018).

\section{Phytotoxicity assay}

In this study, the toxicity of three organic substrates was assessed through the seed germination test (Tam and 
Tiquia, 1994). The substrates were extracted in distilled water $(1: 10 \mathrm{w} / \mathrm{v})$ and shaken for $30 \mathrm{~min}$, then filtered. Three plant species, roselle (Hibiscus sabdariffa), okra (Abelmoschus esculentus) and rice (Oryza sativa), were selected. Seed surface was sterilized by soaking in $6 \%$ Clorox solution for $5 \mathrm{~min}$ and rinsed three times in distilled water. The treated seeds, ten seeds per dish, were placed in sterile petri plates lined with tissue paper. Then, $5 \mathrm{~mL}$ of extract solution was added to the plates and incubated in the dark for seven days. For the control, sterilized distilled water was added. Further, a solution of chemical fertilizer, distilled water $=1$ : 50 , was used as a positive control. After seven days, the number of germinated seeds and seedling length (root length and shoot length) were recorded.

Relative growth index (RGI) is categorized as follows: (1) $0<\mathrm{RGl}<0$.8: inhibition; (2) $0.8<\mathrm{RGI}<1.2$ : no significant effect; (3) RGI>1.2: stimulation root growth (Young et al., 2012).

$$
\mathrm{RGI}=\frac{\text { Mean of root length in sample }}{\text { Mean of root length in control }}
$$

Germination index (GI) was based on the germination rate (GR) and RGI using the following equation (2):

$$
\begin{aligned}
& \text { GR (\%) }=\frac{\text { Mean of germinated seed in sample }}{\text { Mean of germinated seed in control }} \times 100 \\
& \text { GI }(\%)=\text { RGI } \times \text { GR (2) }
\end{aligned}
$$

The maturity of substrates was assumed when GI > 80\% (Iglesias-Jiménez and Pérez-García, 1992).

Vigor Index $(\mathrm{VI})=$ Germination percentage $\times$ Seedling length (3)

\section{Experimental design and data analysis}

All experiments were arranged by completely randomized design with three replications. Analysis of variance (ANOVA) was used to analyze the data using Statistic 10 and Microsoft Excel software. The significant differences between treatments were determined by a Least Significant Difference (LSD) test at $\mathrm{P}<0.05 \%$.

\section{RESULTS AND DISCUSSION}

\section{Organic amendment's properties}

Physicochemical analysis of three organic amendments and soil are shown in Table 1 . All substrates were slightly alkaline, had low salinity and high $\mathrm{OM}$. The $\mathrm{pH}$ of the three substrates ranged from 7.47-7.82. According to Moore (2001), a pH range of $5.5-8$ is suitable for plant growth and most soil biological processes, including nutrient cycling and microbial activity. Electrical conductivity (EC) is one of most noticeable chemical features of organic amendments. The EC value indicates the amount of salt in an amendment that may negatively affect on plant growth or soil salinity. In this test, SMS had the highest electrical conductivity $\left(1.57 \mathrm{dSm}^{-1}\right)$, followed by others in the following order: SMS > filter cake > fermented grass. These low EC values reflected no negative effects on soil EC. Moisture of all substrates varied in range from $10.73 \%$ to $22.05 \%$. Deepesh et al. (2014) reported that moisture content in good quality organic amendment is around $50-55 \%$. The moisture and $\mathrm{OM}$ of the tested soil was extremely low $(2.22 \%, 0.67 \%)$ due to its sandy texture. Most soils in the northeast region of Thailand are poor in OM as well as fertility.

Table 1 also presents information about nutrient content in the three substrates and soil. Generally, organic matter can be used as fertilizers or conditioners depending on their nutrient content. All substrates in this test were low in nutrient availability but were rich sources of organic carbon. Filter cake got the highest amount of nutrient elements ( $\mathrm{N} 2.45 \%, \mathrm{P} 1.86 \%$ and $\mathrm{K} 0.58 \%$ ) and the lowest $\mathrm{C} / \mathrm{N}$ ratio $(8: 1)$ in comparison with the other two. Nutrient content in SMS and fermented grass was quite low (ranging from $0.14 \%$ to $0.75 \%$ ). The critical $\mathrm{C} / \mathrm{N}$ ratio $(59: 1)$ in SMS was the consequence of high OM amounts $(74.9 \%)$. The $\mathrm{C} / \mathrm{N}$ ratio is one important index to assess the decomposition rate and the type of nitrogen released during the decomposition of OM. Some research suggests the ideal $\mathrm{C} / \mathrm{N}$ ratio for $\mathrm{OM}$ decomposition is between 20 to 30 (Marthur et al., 1993;

\begin{tabular}{|c|c|c|c|c|c|c|c|c|c|}
\hline & $\mathrm{pH}$ & $\begin{array}{c}\mathrm{EC} \\
\mathrm{dSm}^{-1}\end{array}$ & $\begin{array}{c}\text { Moisture } \\
\%\end{array}$ & $\begin{array}{l}\mathrm{TN} \\
\%\end{array}$ & $\begin{array}{l}\text { TP } \\
\%\end{array}$ & $\begin{array}{l}\text { TK } \\
\% \\
\end{array}$ & $\begin{array}{l}\text { OM } \\
\%\end{array}$ & $\begin{array}{l}\mathrm{OC} \\
\%\end{array}$ & $\mathrm{C} / \mathrm{N}$ \\
\hline $\mathrm{FC}$ & $7.47 \pm 0.02 c$ & $0.52 \pm 0.06 b$ & $10.73 \pm 1.02 \mathrm{c}$ & $2.45 a$ & $1.86 a$ & $0.58 a$ & $34.30 b$ & $18.5 b$ & $8: 1 c$ \\
\hline$F G$ & $7.82 \pm 0.03 a$ & $0.26 \pm 0.03 c$ & $19.61 \pm 0.81^{b}$ & $0.75 b$ & $0.14 \mathrm{c}$ & $0.20 \mathrm{c}$ & $33.14 c$ & $16.56 c$ & $22: 1 b$ \\
\hline SMS & $7.72 \pm 0.02 b$ & $1.57 \pm 0.06 a$ & $22.05 \pm 1.99 a$ & $0.72 c$ & $0.21 b$ & $0.68 b$ & 74.9.1a & $42.49 a$ & $59: 1 a$ \\
\hline Soil & $7.09 \pm 0.04 d$ & $0.05 \pm 0.003 d$ & $2.22 \pm 0.32^{d}$ & $0.05 d$ & $0.11 d$ & $1.62 \mathrm{~d}$ & $0.67 d$ & $0.4 d$ & $8: 1 d$ \\
\hline
\end{tabular}
Epstein, 1998).

Table 1: Some physicochemical characteristics in three organic amendments in comparison with normal soil.

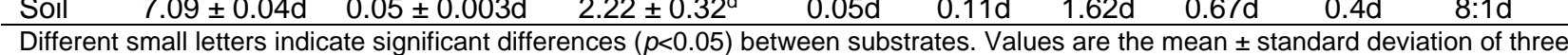
replications (Standard deviation <10\%); EC: electrical conductivity; FC: filter cake; SMS: spent mushroom substrate; FG: fermented grass; TN: total nitrogen; TP: Total phosphorus; TK: Total potassium; OM: organic matter; OC: organic carbon; C/N: organic $\mathrm{C} /$ total N 
A low $\mathrm{C} / \mathrm{N}$ ratio of organic amendments may limit the growth of microorganism, which in turn decreases decomposition rates (Berg and McClaugherty, 2003). Meanwhile, a high amount of carbon compounds required strong activity of the microbial population; therefore, microorganisms use soil nitrogen for their growth and cause immobilization of soil nitrogen (Lucas et al., 2014). A high number of organic particles need a long time to degrade. This allows organic matter to remain in the soil longer, consequently, supporting soil structure and other biological activities. Some research demonstrates that organic amendments, which are rich in cellulose, can enhance fungal activity and improve soil structure by soil aggregate formation (Lucas et al., 2014). Moreover, high nitrogen material should be added to reach appropriate $\mathrm{C} / \mathrm{N}$ ratios before using these substrates in soil.

\section{Microbial activity}

Microbial activity was determined using both direct (total microorganism and PGPB population) and indirect methods (enzyme activity).
The results in Table 2 reveal differences in the microbial community among substrates. Generally, all substrates were abundant in microbial populations as well as PGPB. Fermented grass had the highest population $(\mathrm{P}<0.01)$ of total microorganisms $\left(4.47 \times 10^{7} \mathrm{CFU} / \mathrm{g}\right)$, nitrogen fixing bacteria $\left(1.08 \times 10^{6} \mathrm{CFU} / \mathrm{g}\right)$ and potassium solubilizing bacteria $\left(1.84 \times 10^{6} \mathrm{CFU} / \mathrm{g}\right)$. SMS and filter cake had similar populations of total microorganisms (1.62 $\times 10^{7} \mathrm{CFU} / \mathrm{g}$ and $1.26 \times 10^{7} \mathrm{CFU} / \mathrm{g}$, respectively) and nitrogen fixing bacteria $\left(8.13 \times 10^{5} \mathrm{CFU} / \mathrm{g}\right.$ and $7.77 \times 10^{5}$ $\mathrm{CFU} / \mathrm{g}$, respectively). SMS was the richest source of PSB $\left(2.3 \times 10^{5} \mathrm{CFU} / \mathrm{g}\right)$. Soil tested in this experiment was too poor in the number of both PSB and KSB $\left(1.2 \times 10^{2},<10^{2}\right.$ $\mathrm{CFU} / \mathrm{g}$, respectively).

The FDA and DHA activity of all samples are presented in Figure 1. All amendments had high enzyme activities in both FDA and DHA activity. Most microorganisms, including fungi, bacteria, some protozoa and algae, were involved in FDA hydrolysis activity (Schnurer and Rosswall,1982).

Table 2: Total microorganism and PGPB populations in three organic substrates and normal soil.

\begin{tabular}{|c|c|c|c|c|}
\hline & TM & NFB & PSB & KSB \\
\hline Substrates & \multicolumn{4}{|c|}{$\mathrm{CFU} / \mathrm{g}$} \\
\hline $\mathrm{FC}$ & $1.26 \times 107^{b}$ & $7.77 \times 105^{c}$ & $8.02 \times 104^{b}$ & $1.01 \times 105^{c}$ \\
\hline SMS & $1.62 \times 107^{b}$ & $8.13 \times 105^{c}$ & $2.3 \times 105^{a}$ & $2.07 \times 104^{b}$ \\
\hline $\mathrm{FG}$ & $4.47 \times 107^{a}$ & $1.08 \times 106^{\mathrm{b}}$ & $5.43 \times 104^{c}$ & $1.84 \times 106^{\mathrm{a}}$ \\
\hline Soil & $5.7 \times 106^{c}$ & $1.54 \times 106^{a}$ & $1.2 \times 102^{d}$ & $<102^{d}$ \\
\hline
\end{tabular}

Different small letters indicate significant differences $(p<0.05)$ among substrates. Values are the mean of three replications FC: filter cake; SMS: spent mushroom substrate; FG: fermented grass; TM: total microorganism; NFB: nitrogen fixing bacteria; PBS: phosphorus solubilizing bacteria; KSB: potassium solubilizing bacteria.

FDA activity

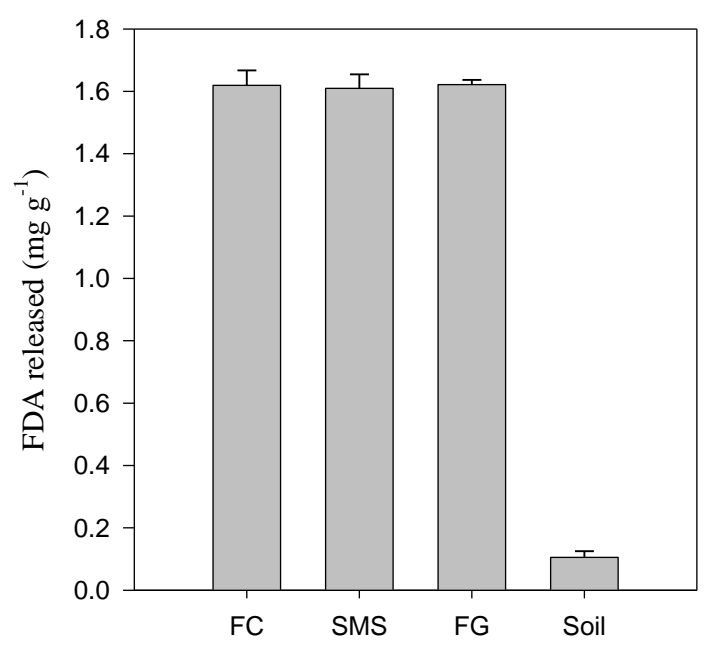

Substrates
DHA activity

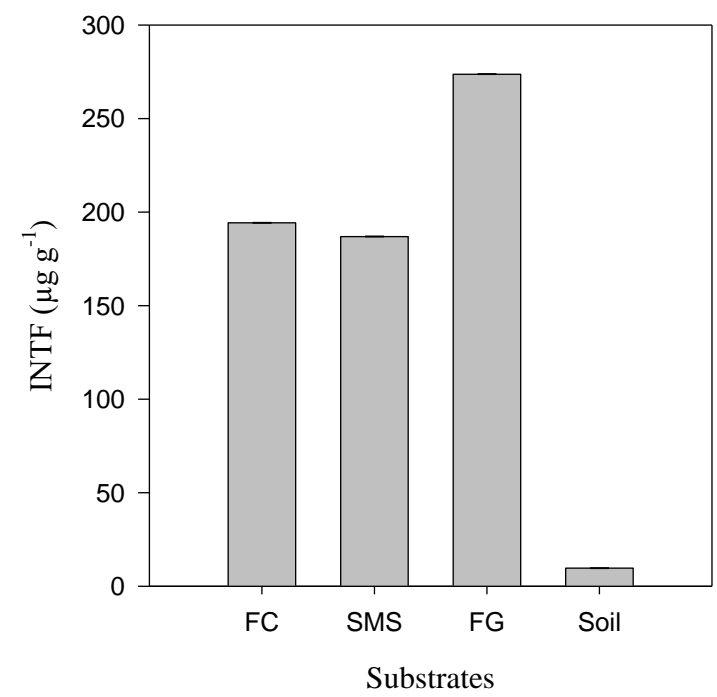

Figure 1: FDA and DHA activity in three organic substrates and normal soil. 
FDA is catalyzed by various microbial enzymes such as proteases, lipases and esterases. In this test, FDA hydrolysis in three organic substrates was similar and ranged from 1.609 to $1.621 \mathrm{mg} / \mathrm{g}$. Sánchez-Monedero et al. (2008) found the significant difference between FDA hydrolysis and microbial biomass in soil added with various organic amendments regardless of the origin, composition and degree of stability of the organic amendments. Meanwhile, the highest DHA $(P<0.01)$ among the three amendments were found in fermented grass $(273.64 \mu \mathrm{g} / \mathrm{g})$. The DHA in SMS and filter cake were not significantly different but had high values $(186.90 \mu \mathrm{g} / \mathrm{g}$, $194.22 \mu \mathrm{g} / \mathrm{g}$, respectively). Wolińska et al. (2012) demonstrate the main role of DHA enzymes in OM decomposition through high correlation coefficients of enzymatic activities and total organic carbon. However, the $\mathrm{C} / \mathrm{N}$ ratio is the main factor affecting microbial activity, which explains why fermented grass had the highest DHA. The tested soil presented the lowest amount of FDA and DHA $(0.105 \mathrm{mg} / \mathrm{g}, 9.65 \mu \mathrm{g} / \mathrm{g})$.

\section{Seed germination}

The Germination Index (GI) indicates the presence of phytotoxins that influence both seed germination and root elongation (Emino and Warman, 2004). The effects of different organic amendments' extraction on each kind of seed germination displayed dissimilar patterns (Table 3).
Differences of $\mathrm{GI}$ and $\mathrm{VI}$ in $A$. esculentus and $O$. sativa responded by seedling growth parameters (root length or shoot length); however, in $\mathrm{H}$. sabdariffa, these differences were mainly due to reduced germination. Filter cake and SMS showed promotion in seed germination of $A$. esculentus (RGI $>1.2$, GI $>80 \%$ ) and no inhibition effect on the seed germination of $O$. sativa and $H$. sabdariffa $(0.8<R G \mid<1.2, \mathrm{Gl}>80 \%)$. Extraction of filter cake and SMS did not significantly affect either root elongation or the germination rate of $O$. sativa and $H$. sabdariffa in comparison with the control. Meanwhile, the promoting activity of these substrates on the Gl of $A$. esculentus was completely due to stimulation of root growth (RGI ranging 1.48-1.88); in turn, their $\mathrm{Gl}$ was significant higher $(\mathrm{P}<0.01)$ than other treatments. On the other hand, fermented grass had no effect on the seed germination parameters of $A$. esculentus in comparison with the control. However, this substrate also showed root elongation promotion of $O$. sativa (RGI 1.2), but inhibited germination rates $(73.33 \%)$ of $H$. sabdariffa. The negative impact on the Gl of $H$. sabdariffa was also found in soil extraction. This may be due to the sensitivity of $H$. sabdariffa with some unknown components in fermented grass and soil. Soil extraction did not reveal inhibition on $\mathrm{Gl}$ or $\mathrm{VI}$, while chemical solution totally inhibited germination parameters of all seed (Table 3).

Table 3: Phytotoxicity effects of three organic amendments and soil on germination parameters of three kinds of seed.

\begin{tabular}{|c|c|c|c|c|c|c|}
\hline & $\begin{array}{l}\text { Root } \\
\text { (cm) }\end{array}$ & $\begin{array}{c}\text { Shoot } \\
\text { (cm) }\end{array}$ & RGI & $\begin{array}{l}\text { GP } \\
(\%)\end{array}$ & $\begin{array}{c}\text { GI } \\
(\%)\end{array}$ & VI \\
\hline \multicolumn{7}{|c|}{ Oryza sativa } \\
\hline $\begin{array}{l}\text { Control } \\
\text { FC } \\
\text { SMS }\end{array}$ & $\begin{array}{l}6.13 \pm 0.14^{\mathrm{c}} \\
4.96 \pm 0.21^{\mathrm{d}} \\
5.78 \pm 0.11^{\mathrm{cd}}\end{array}$ & $\begin{array}{l}3.33 \pm 0.21^{\mathrm{a}} \\
2.61 \pm 0.35^{\mathrm{b}} \\
3.19 \pm 0.34^{\mathrm{a}}\end{array}$ & $\begin{array}{l}1.00 \\
0.81 \\
0.94\end{array}$ & $\begin{array}{c}96.67 \\
100.00^{a} \\
90.00^{a b}\end{array}$ & $\begin{array}{c}100.00 \\
83.75 \\
87.84\end{array}$ & $\begin{array}{l}945.33 \\
783.45 \\
835.14\end{array}$ \\
\hline $\begin{array}{l}\text { FG } \\
\text { Soil }\end{array}$ & $\begin{array}{l}7.29 \pm 0.76^{b} \\
8.43 \pm 0.37^{a}\end{array}$ & $\begin{array}{l}3.35 \pm 0.35^{\mathrm{a}} \\
3.25 \pm 0.28^{\mathrm{a}}\end{array}$ & $\begin{array}{l}1.18 \\
1.36\end{array}$ & $\begin{array}{l}100.00^{a} \\
100.00^{a}\end{array}$ & $\begin{array}{l}123.03 \\
142.28\end{array}$ & $\begin{array}{l}1100.69 \\
1207.59\end{array}$ \\
\hline \multicolumn{7}{|c|}{ Hibiscus sabdariffa } \\
\hline $\begin{array}{l}\text { Control } \\
\text { FC }\end{array}$ & $\begin{array}{l}4.00 \pm 0.73^{a} \\
3.59 \pm 0.51^{a}\end{array}$ & $\begin{array}{l}5.61 \pm 0.88^{a} \\
5.99 \pm 1.64^{a}\end{array}$ & $\begin{array}{l}1.00 \\
0.90\end{array}$ & $\begin{array}{l}90.00^{a} \\
90.00^{a}\end{array}$ & $\begin{array}{c}100.00 \\
89.75\end{array}$ & $\begin{array}{l}960.67 \\
958.00\end{array}$ \\
\hline $\begin{array}{l}\text { SMS } \\
\text { FG }\end{array}$ & $\begin{array}{l}4.40 \pm 0.61^{\mathrm{a}} \\
3.60 \pm 1.17^{\mathrm{a}}\end{array}$ & $\begin{array}{l}6.00 \pm 1.35^{\mathrm{a}} \\
5.46 \pm 0.61^{\mathrm{a}}\end{array}$ & $\begin{array}{l}1.09 \\
0.90\end{array}$ & $\begin{array}{l}83.33^{a b} \\
73.33^{b c}\end{array}$ & $\begin{array}{c}101.77 \\
73.33\end{array}$ & $\begin{array}{l}962.96 \\
737.95\end{array}$ \\
\hline $\begin{array}{l}\text { Soil } \\
\text { CF }\end{array}$ & $\begin{array}{l}3.63 \pm 0.16^{\mathrm{a}} \\
1.61 \pm 0.90^{\mathrm{b}}\end{array}$ & $\begin{array}{l}5.66 \pm 0.30^{a} \\
2.65 \pm 0.88^{b}\end{array}$ & $\begin{array}{l}0.91 \\
0.43\end{array}$ & $\begin{array}{l}76.67^{b c} \\
66.67^{c}\end{array}$ & $\begin{array}{l}77.23 \\
29.88\end{array}$ & $\begin{array}{l}791.09 \\
316.05\end{array}$ \\
\hline \multicolumn{7}{|c|}{ Abelmoschus esculentus } \\
\hline Control & $2.18 \pm 0.32^{c}$ & $1.81 \pm 0.37^{c}$ & 1.00 & $100.00^{a}$ & 100.00 & 398.67 \\
\hline $\begin{array}{l}\text { FC } \\
\text { SMS }\end{array}$ & $\begin{array}{l}3.22 \pm 0.22^{\mathrm{b}} \\
4.09 \pm 0.38^{\mathrm{a}}\end{array}$ & $\begin{array}{l}3.64 \pm 0.68^{\mathrm{a}} \\
3.91 \pm 0.25^{\mathrm{a}}\end{array}$ & $\begin{array}{l}1.48 \\
1.88\end{array}$ & $\begin{array}{l}100.00^{a} \\
100.00^{a}\end{array}$ & $\begin{array}{l}147.55 \\
187.77\end{array}$ & $\begin{array}{l}685.67 \\
800.67\end{array}$ \\
\hline $\begin{array}{l}\text { FG } \\
\text { Soil } \\
\text { CF }\end{array}$ & $\begin{array}{c}2.42 \pm 0.53^{\mathrm{c}} \\
2.03 \pm 0.19^{\mathrm{c}} \\
0.00 \pm 0^{\mathrm{d}}\end{array}$ & $\begin{array}{l}2.45 \pm 0.18^{\mathrm{b}} \\
1.44 \pm 0.21^{\mathrm{cd}} \\
0.83 \pm 0.09^{\mathrm{d}}\end{array}$ & $\begin{array}{l}1.1 \\
0.93 \\
0.00\end{array}$ & $\begin{array}{c}100.00^{\mathrm{a}} \\
96.67^{\mathrm{a}} \\
0.00^{\mathrm{b}}\end{array}$ & $\begin{array}{c}110.86 \\
90.16 \\
0.00\end{array}$ & $\begin{array}{c}486.33 \\
335.76 \\
0.00\end{array}$ \\
\hline
\end{tabular}

Different small letters indicate significant differences $(p<0.05)$ among substrates; RGl: Relative growth index; GP: germination percentage; Gl: germination index; VI: vigor index; FC: filter cake; SMS: spent mushroom substrate; FG: fermented grass; CF: chemical fertilizer in water ratio $1: 50$ 
The increase in $\mathrm{Gl}$ and $\mathrm{VI}$ may come from PGPB activity within organic amendments. Some undesirable compounds such as high salts, heavy metals, pathogens and toxins caused adverse effects on plant growth (Tam and Tiquia 1994; Ferreras et al. 2006). Thus, GI $>80 \%$ is one of the main indexes to evaluate phytotoxicity of compost (Tam and Tiquia, 1994; Tiquia and Tam, 1998). However, GI is not sensitive enough to distinguish immature and mature substrates (Emino and Warman, 2004). The study of Saidi et al. (2009) shows that the most appropriate parameters to evaluate the maturity degree of compost include the $\mathrm{C} / \mathrm{N}$ ratio $<15 ; \mathrm{NH}_{4}^{+}-\mathrm{N}<$ $400 \mathrm{mg} / \mathrm{kg}$; $\mathrm{CO}^{2}-\mathrm{C}<2000 \mathrm{mg} \mathrm{CO} 2-\mathrm{C} / \mathrm{kg}$; dehydrogenase activity $<1 \mathrm{mg}$ TPF/g dry matter and germination index $>$ $80 \%$. Some studies find that GI has a positive correlation with $\mathrm{NO}^{3}-\mathrm{N}, \mathrm{P}$ and $\mathrm{K}$ content (Zayed and Atta, 2012) and a negative correlation with $\mathrm{EC}$ and carbon mineralization rates (Aslam et al., 2008). Until now, the correlation between enzyme activity and toxicity in organic compost has not been found. Microbial activity is a good indicator for the stability of organic matter decomposition rather than toxicity.

From the above results, we conclude that all three organic substrates are suitable to be soil amendments. Fermented grass and filter cake, with considerable amounts of nutrients and moderate $\mathrm{C} / \mathrm{N}$ ratios, could be used directly on soils to support fertility, whereas SMS is a good source for maintaining $\mathrm{OM}$ and improving soil structure in the long term.

\section{ACKNOWLEDGEMENTS}

We would like to thank Assoc. Prof. Dr. Piyada Theerakulpisut for suggestions on data writing. The author would like to thank Khon Kaen University (KKU scholarship) and the Salt-tolerant Rice Research Group, Faculty of Science, Khon Kaen University for supporting this study

\section{REFERENCES}

Adam, G. and Duncan, H. (2001). Development of a sensitive and rapid method for the measurement of total microbial activity using fluorescein diacetate (FDA) in a range of soils. Soil Biology and Biochemistry 33, 943-951.

Adugna, G. (2016). A review on impact of compost on soil properties, water use and crop productivity. Academic Research Journal of Agricultural Science and Research 4, 93-104.

Aslam, D. N., William, H., and Jean, S. V. (2008). Comparison of several maturity indicators for estimating phytotoxicity in compost-amended soil. Waste Management 28(11), 2070-2076.

Berg, B. and McClaugherty, C. (2003). Plant Llitter: Decomposition, Humus Formation, Carbon Secuestration. Berlin, DE: (c) Springer-Verlag Berlin Heidelberg. pp. 283.

Bot, A. and José, B. (2005). The Importance of Soil Organic Matter. FAO Soils Bulletin. pp. 1-80.
Burns, R. G. (1982). Enzyme activity in soil: Location and a possible role in microbial ecology. Soil Biology and Biochemistry 14(5), 423-427.

Deepesh, V., Verma, V. K., Suma, K., Swathi, A., Gnanavelu, V. and Madhusudanan V. (2014). Evaluation of an organic soil amendment generated from municipal solid waste seeded with activated sewage sludge. Journal of Material Cycles and Waste Management 273-286.

Diacono, M. and Francesco, M. (2010). Long-term effects of organic amendments on soil fertility. A review. Agronomy for Sustainable Development 30, 401-422.

Emino, E. R. and Warman, P.R. (2004). Biological assay for compost quality. Compost Science and Utilization 12(4), 342-48.

Epstein, E. (1998). The science of composting. Journal of Environment Quality 27(1), 246.

Ferreras, L., Elena, G., Silvia, T., Inés F., and Rossana R. (2006). Effect of organic amendments on some physical, chemical and biological properties in a horticultural soil. Bioresource Technology 97(4), 635640.

Franzlubbers, A. J. and Haney, R. L. (2006). Assessing soil quality in organic agriculture critical issue report. Soil Quality pp. 1-17.

Gaspar, M. L., Cabello, M. N., Pollero, R. and Aon, M. A. (2001). Fluorescein diacetate hydrolysis as a measure of fungal biomass in soil. Current Microbiology 42(5), 339-344.

Hu, X., Chen, J. and Guo, J. (2006). Two phosphatesand potassium-solubilizing bacteria isolated from Tianmu mountain, Zhejiang, China. World Journal of Microbiology and Biotechnology 22(9), 983-990.

Iglesias Jiménez, E. and Perez Garcia, V. (1989). Evaluation of city refuse compost maturity: A review. Biological Wastes 27(2), 115-142.

Iglesias Jiménez, E. and Perez Garcia, V. (1992). Determination of maturity indices for city refuse composts. Agriculture, Ecosystems and Environment 38(4), 331-343.

Larney, F. J. and Angers, D. A. (2012). The role of organic amendments in soil reclamation: A review. Canadian Journal of Soil Science 92, 19-38.

Lucas, S. T., D'angelo, E. M. and Williams, M. A. (2014). Improving soil structure by promoting fungal abundance with organic soil amendments. Applied Soil Ecology 75, 13-23.

Marthur, S., Owen, G., Dinel, H. and Schnitzer, M. (1993). Determination of compost biomaturity. I. Literature review. Biological Agriculture and Horiculture 10(2), 65-85.

Moore G. (2001). Soilguide: A handbook for understanding and managing agricultural soils. Australia: Agric. West Aust. Bull., pp.53-63

Nautiyal, S. C. (1999). An efficient microbiological growth medium for screening phosphate solubilizing microorganisms. FEMS Microbiology Letters 170(1), 265-270. 
Pascual, J. A., Garcia, C., Hernandez, T., Moreno, J. L. and Ros, M. (2000). Soil microbial activity as a biomarker of degradation and remediation processes. Soil Biology and Biochemistry 32(13), 1877-1883.

Saidi, N., Kouki, S. M' Hiri, F., Jedidi, N., Mahrouk, M., Hassen, A. and Ouzari H., (2009). Microbiological parameters and maturity degree during composting of posidonia oceanica residues mixed with vegetable wastes in semi-arid pedo-climatic condition. Journal of Environmental Sciences 21(10),1452-1458.

Sánchez-Monedero, M. A, Mondini, C., Cayuela, M. L., Roig, A. and Contin, M. and De Nobili, M. (2008). Fluorescein diacetate hydrolysis, respiration and microbial biomass in freshly amended soils. Biology and Fertility of Soils 44(6), 885-890.

Schnurer, J. and Rosswall, T. (1982). Fluorescein diacetate hydrolysis as a measure of total microbial activity in soil and litter. Applied Environmental Microbiology. 43(6),1256-1261.

Selim, S., Zayed, M. and Houssam M. (2012). Evaluation of phytotoxicity of compost during composting process. Nature and Science 10(2), 69-77.

Silva, J. A. and Hue, N. V. (2000). Organic soil amendments for sustainable agriculture: Organic sources of nitrogen, phosphorus, and potassium. In: Plant Nutrient Management in Hawaii's Soils, Approaches for Tropical and Subtropical Agriculture. College of Tropical Agriculture and Human Resources, University of Hawaii at Manoa. pp. 133-144.

Sultana B. (2011). Effects of organic amendment on soil quality as assessed by biological indicators. Ph.D. Dissertation. University of Naples Federico II.

Tam, N. F. Y. and Tiquia, S. M. (1994). Assessing toxicity of spent pig litter using a seed germination technique. Resources, Conservation and Recycling 11(1-4), 261274.

Tiquia, S. M. and Tam, N. F. Y. (1998). Elimination of phytotoxicity during co-composting of spent pigmanure sawdust litter and pig sludge. Bioresource Technology 65(1-2), 43-49.

Tiquia, S. M, Tam, N. F. Y. and Hodgkiss, I. J. (1996). Effects of composting on phytotoxicity of spent pigmanure sawdut litter. Environmental Pollution 93(3), 249-256.

Trevors, J.T. (1984). Effect of substrate concentration, inorganic nitrogen, $\mathrm{O}_{2}$ concentration, temperature and $\mathrm{pH}$ on dehydrogenase activity in soil. Plant and Soil 77, 285-293.

von Mersi, W. and Schinner, F. (1991). An improved and accurate method for determining the dehydrogenase activity of soils with iodonitrotetrazolium chloride. Biology and Fertility of Soils 11(3), 216-220.

Warman, P. R. (1999). Evaluation of seed germination and growth tests for assessing compost maturity. Compost Science and Utilization 7(3), 33-37.

Wolińska, A. and Stępniewska, Z. (2012). Dehydrogenase activity in the soil environment. In: Dehydrogenases. pp.183-210.

Young, B. J., Riera, N. I., Beily, M. E., Bres, P. A., Crespo, D. C. and Ronco, A. E. (2012). Toxicity of the effluent from an anaerobic bioreactor treating cereal residues on lactuca sativa. Ecotoxicology and Environmental Safety 76(1), 182-186. 